\title{
Examining the Role of the Culture of Local Government on Adoption and Use of E-Government Services
}

\author{
Nurdin Nurdin ${ }^{*}$, Rosemary Stockdale, and Helana Scheepers \\ Faculty of Information and Communication Technologies \\ Swinburne University of Technology \\ nnurdineswin.edu.au, rstockdaledswin.edu.au, \\ hscheepers@swin.edu.au
}

\begin{abstract}
This paper describes research in progress to explore the role of culture in adoption of e-government at local government levels. The majority of research in electronic government highlighted cultural issues but they do not identify specific cultural traits influencing e-government adoption and use. From our literature review we identified four major cultural traits; adaptability, involvement, mission, and bureaucratic, that is explored in this research. Based on these cultural traits and other cultural issues surrounding the adoption of egovernment, we develop a framework to explore the role of culture in adopting and using e-government systems at local government organizations. Evidences suggest that the adoption of e-government at local levels is either mandatory or voluntary which is followed by supportive policies from central governments. Our conclusion is that during the adoption process, the cultural traits contribute to the adoption and use of e-government systems.
\end{abstract}

Keywords: Organizational culture, e-government, adoption, local government.

\section{Introduction}

Research into the adoption of technology at organizational level has mainly focused on technological issues [1,2], with fewer studies conducted on non-technical factors such as organizational culture and individuals within organizations [3]. The absence of considering cultural consequences in the adoption of technology at organizational level may lead to the failure of the adoption process as there are direct impacting influences between culture and information technology (IT) and between an organization's culture and its IT users [4]. Therefore adoption of technology by organizations should also focus on the organizational and cultural issues because culture plays a role as a significant success factor [5], and as a barrier to adoption [6].

The adoption of electronic government initiatives is no different from commercial information systems. Although some researchers have found that the success of egovernment adoption is determined by technological factors [7], others have identified

* On leave from STAIN Datokarama Palu, Indonesia. 
cultural elements that contribute to electronic government adoption and use [8,9]. Transferring technology from developed countries to developing countries or from private to public organizations has also caused cultural gaps that need to be addressed [10]. We thus recognize that culture exists in the context of e-government adoption and use, although few researchers or practitioners devote attention to the cultural issues during new technology adoption in government organizations at either central or local levels.

This research explores the role of cultural dimensions in adopting e-government at local government level. We examine how specific cultural dimensions have a role in local government technology adoption through a complex interweaving between technology and government. This leads us to form the research question as follows what cultural and sub-cultural dimensions play a role in local government technology initiatives, and how do they contribute to the adoption and use of local-e-government systems? The contribution of this paper is the development of a deeper understanding of the role of cultural dimensions in the adoption and use of local electronic government.

The paper is organised as follows. First we define and discuss organizational culture before addressing the concept of e-government technology adoption at local level. We then examine four cultural dimensions and other sub cultural dimensions derived from organizational culture theories, which are operationalized in the context of e-government adoption. This is followed by a discussion of the cultural dimensions, which focus on external orientation and internal integration, as well as change and flexibility, and stability and direction. Finally the identified constructs are brought together to build a framework that will inform the next stage of the research into the role of culture in the adoption of local e-government initiatives.

\section{Understanding Organizational Culture}

The term culture has been widely used at national and organizational level. However, there is no single universal definition for culture. Hofstede [11] defines culture as "programming of the mind which distinguishes the members of one human group from another". Sathe [12] said culture is "the set of important understanding (often unstated) that members of a community share in common". Meanwhile, organizational culture is defined by Denison [13] as "the underlying values, belief, and principles that serve as a foundation for an organization's management system as well as the set of management practices and behaviour that both exemplify and reinforce those basic principles".

An organization's culture forms the personality of the organization [14] through the socialization process of people in the workplace of the organization [15]. It becomes a beneficial asset for an organization if it supports the organization's mission, goals and strategies [16] and plays an important role in many aspects of the organization [17]; for example culture plays a role in the statement of mission and goals of the organization, and indirectly shapes behaviour [18]. Through organizational culture, individuals inside the organization obtain a common understanding of the core 
mission of their organization and that leads to consensus development on how to achieve organizational goals.

Organizational culture which is derived from individuals' experience and history is unique [19]. Certain organizations might have a strong culture while others might not, depending on how the culture is derived and established within the firm. A strong organizational culture, which is useful for organizations' development, is embedded in the long term interaction of its members in coping with external adaptation and internal integration [20]. This strong culture, then, can be used to counter internal and external problems [21] in maintaining the organization's survival in turbulent situations.

\section{Electronic Local Government Adoption and Use}

The adoption of technology in e-government has many similarities to that of an organization where decisions are made at a senior level and then assimilated into the organization [22]. The process of adoption may be mandated or voluntary [23, 24]. In certain contexts, voluntary adoption is more successful $[23,25,26]$, while in another situation mandatory policy is the only way to induce technology usage because it can encourage the initial behaviour to adopt technology [27]. For example, a senior manager may drive primary adoption of innovation after identifying objectives to change some aspects of the business and then mandate the organization to adopt the technology [28]. In other words, both mandatory and voluntary adoption strategies offer the promise of successful technology adoption in the relevant context and situation.

This concept is no different from the adoption of technology in local government organizations where the use of technology is sometimes initiated by central governments through setting of certain goals or it is initiated at grassroots levels. A mandatory approach may exist in e-government adoption due to political nature and law-abiding citizens [29]. For example, the UK government launched a modernization agenda in 1997 to transform local authorities' performance across the UK. This new agenda has resulted in the implementation of electronic government at local level across the UK [30]. In a further step, the UK central government set "e-government targets" which mandated all government agencies to provide on-line interactions between government agencies and the public by 2005 [31]. Failure to conform to these policies and regulations can result in imposing of sanctions by central governments such as withdrawing funding that has been allocated to local governments [32]. Similarly, a mandatory approach was considered to have a significant impact on the success of the Smart Cards adoption in the medical sectors in Canada [33]. These examples show that a central government has the power to impose the adoption of e-government on local government bodies by delivering policies and regulations to improve governments' services.

A mandating policy to adopt e-government includes imposing processes, values, competencies and systems [34]. Heeks [34] argues that implementing e-government requires or imposes the formality of process and management, involves the role and skills of people, and is subjected to the rationality of organizational culture. In other words, central governments should contribute to e-government adoption at local level by supporting the change of management, empowering people to increase involvement, and adjustment of organizational culture to new technology. 
However, in the US context, the adoption of e-government at local levels was initiated at grassroots levels in 2000 due to the demand of the citizens $[35,36]$ while the E-Government Act, which includes the planning of an e-government strategy and initiative implementation, was launched in 2002 [37]. This means the initiatives were developed on the basis of local government initiatives while in the next step the central government provided guidelines to support better implementation of the initiatives. For rapid adoption of e-government, the US government also provides incentives to encourage citizens to use the systems such as giving cost reductions for making online tax transactions through the federal portal [38].

In the developing countries context, the adoption of e-government can also be mandatory or voluntary. For example, the successful adoption of an e-government portal by government departments in Hong Kong was determined by voluntary decision and support from higher level of the government [39]. Similarly, in the case of electronic tax managed by Central Excise in India, the citizens are encouraged, rather than required, to adopt the system [40]. In both cases, the e-government initiatives are voluntarily adopted at lower levels but the initiatives are started at central level not at grassroots such as in the US. However, in contrast, in the case of Tanzanian's Integrated Tax Administration (ITAX) as a part of e-government implementation [41], adoption of the project was mandatory for all tax regions of the country by 2007 . The initiative was under the control of and supported by a task force authority at central level.

E-government infrastructure, such as computer networks, communication systems and shared services are typically belong to various of entities at local and central levels which need a cohesiveness and dynamicity in its implementation [42]. This means both central and local government entities are involved in electronic local government development regardless whether the initiatives are mandatory or voluntary. Central government might provide ongoing supports because successful e-government projects may be abandoned or not sustained after years of adoption if supportive infrastructure, such as financial, political, technical, are terminated [32, 34, 43].

\section{Culture Dimensions in E-Government Adoption}

Researchers have identified many cultural value dimensions or traits; for example Leidner and Kayworth's [44] review of the literature on culture found 46 value dimensions of culture at national, organizational and sub-unit level. Out of those 46 cultural dimensions, four key traits, identified at the level of organizational culture, are indicated in major e-government research [10, 34, 45-48] and are therefore adopted as relevant to our study. These traits are those of adaptability, involvement and mission as identified by Denison and Mishra [17] and the trait of bureaucracy identified by Wallach [16].

Denison and Mishra's framework has been applied to empirical studies to examine cultural issues in a range of environments. Gateo and Wausi [49] applied the framework to understand organizational culture and the adaptation of technology in the Kenyan University system while Dasgupta and Gupta [8] used the framework together with Davis's TAM theory to explore the role of culture in internet adoption in India. Schaper and Pervan's [50] study examined some aspects of the framework in 
the context of e-government in Australia. However, these latter studies are broader in their examination of adoption beyond purely cultural influences, and the cultural traits from Denison and Mishra's framework have not been used in the specific understanding of cultural influences on local e-government adoption.

In examining the four organizational level cultural traits, the bureaucratic element from Wallach's [16] perspective is used to replace the cultural trait of consistency as proposed by Denison and Mishra [17]. Bureaucratic culture is concerned with explicit rules, regulations, and hierarchies in an organization, which is typical of government organizations where such explicit rules are implemented rather than implicit ones as proposed by Denison and Mishra [17] in the consistency cultural traits. The four organizational culture dimensions are discussed in the next sections.

\subsection{Involvement}

Involvement is a subjective psychological state of users which is practiced in forms of participation through behaviour and activities [51]. This cultural trait supports the members of an organization to gain a sense of responsibility, and commitment in the organization because they are highly involved in the organization's activities [17]. Denison and Mishra [17] add that when people in the organization have high involvement, the organization is more productive because they are more committed and responsible towards the organization's interest, but when the organization has low involvement, it experiences difficulties in responding to critical environmental change. However, in our study the concept of people involvement is defined not only by people inside the organization but also people outside the organization, such as citizens, that support the success of e-government adoption.

Low involvement of users influences user participation during the information system development because users' beliefs and attitude are not clearly formed [52]. This can affect the success of a system development adoption in a private or public organization. For example, the wide range of users' participation in e-stamping adoption in Hong Kong has contributed to its successful implementation [53]. This indicates that high participation of users in an organization's activities can determine the achievement of an organization's goals. Their participation is shown in the form of a high commitment to involvement in and support of the organization's projects.

A sense of commitment plays a role in many aspects of the involvement dimension such as in organizational change. This is identified in Rowlinson's [54] study of a public organization in Hong Kong, which experienced difficulties in changing its management when departments had a low level of commitment [54]. Government organizations that adopt new technologies often practice change that requires organizational integration and consolidation between their individuals and organization's interest. During the internal integration, government organizations need highly committed people because they will work hard to achieve organizational goals [55].

Building partnerships between stakeholders such as public, private and citizens [56] can support the success of collaboration in performing organizations' projects. The value of partnership is concerned with the relationship of individuals and organizations in fulfilling participants' shared goals [57]. Jae-Nam and Youne-Gul [57] argue that this partnership value positively affects people's willingness to participate, communicate, to share information, and support the management of organizations. Partners work together and take responsibility to achieve common goals of an organization. 
A sense of responsibility can arise among individuals when they get benefit from the assigned tasks. For example, people get benefit from carrying out the tasks through the job learning that can empower their skill to improve productivity [58]. When individuals gain responsibility values from organizations, they tend to cooperate with each other in accomplishment of organizational tasks. Such cooperation increases the feeling of interdependence among them which results in a heightened sense of responsibilities towards helping others in achieving their goals [59].

In the context of e-government adoption and use, good participation of people through partnership building can enhance adoption as the high level of collaboration by multiple stakeholders will increase the level of acceptance and increase the quality as well as preventing conflict [60]. High levels of collaboration in the adoption of egovernment results in establishing a high sense of responsibility and commitment to support the success of e-government projects, as seen in a study of e-government adoption in Singapore [61]. Stakeholders may include highly committed leaders with strong leadership who want to take real responsibility in facilitating a successful egovernment adoption [53]. They show their commitment through their involvement by viewing information technology as a critical success factor for their organizations [62].

\subsection{Adaptability}

Adaptability is a value of an organization that focuses on external situation demand by developing norms and beliefs that support its capacity to respond to the need for change [17]. In other words, an organization's adaptability is driven by communities from outside of the organization [63]. Community expectations and demands often become a basis for governments in implementing new innovation in their organizations such as the demand of citizens for technology based services that enable them to access government services $24 / 7$.

The development of technology has increased the demand for organizations' environments to be transparent. The transparency, which is driven by the technology, is practiced by organizations not only to their surroundings but also to themselves [64] and is their endeavour to adapt their environment through openness to all stakeholders. In government organizations, openness includes communicating details of systems and decision making to external observers [65]. The willingness of organizations to be transparent can enhance trust building between people inside an organization and external stakeholders and, as a result, contributes to organization responsiveness to their environment.

Trust can create and enhance positive conditions, such as positive interpretation of another's behaviour, which enhances cooperation at group level and raises an organization's performance [66]. Another positive impact is that the cohesion and collaboration between people is facilitated by the presence of the trust value [67]. As a result, collective action of people can be generated and maintained in performing organizational tasks. In addition, when the value of trust is perceived among stakeholders, the organizational risk toward innovative implementation is diminished as people are likely not to perceive the innovation as a risk to them.

Transparency and trust in organizations are driven by external factors. According to Markus external factors influence organizations and people to behave in certain 
ways [68]. This means organizations practice change in responding to external demand by behaving in the way of external factors expectations. Organizational change in certain areas such as in structure, job design, and rewards system are accompanied by cultural changes to avoid resistance from people [20]. The changes help organizations to adapt to new influences from the external environment in order to survive. In certain circumstances, organizational change might be problematic due to the lack of organizational learning or difficulty mobilizing internal support [69].

The lack of organizational learning can be addressed through the building of a learning culture. Organizations learn through individuals developing the capacity to identify and correct errors [70]. Government organizations can also learn from other failure $[10,34]$ to improve their adaptability toward environmental expectations. Local government can learn from the failures they make during the adoption and use of e-government initiative and improve their system through improvisation. Failure can be conceived as a value that provides opportunities to learn what is applicable and what is not applicable in a new system inside their organization. Looking at other local government organizations can also help a local government identify the best actions to be taken in delivering high performance of e-government. During the learning process, local governments can obtain positive values from other successful electronic local government adoptions and then implement them in their own environment.

\subsection{Mission}

Mission is a cultural trait that provides purpose and meaning to an organization and also gives direction and identifies goals that enable an organization to act in an acceptable way $[17,71]$. The organization establishes the mission as an instrument of culture based in the managerial ethos and ideology of the organization and it therefore influences the development of the organization [72]. From the mission statement the organization acquires purpose and meaning as it defines social roles in the organization and designates the roles of employees as related to the organization's role [17]. Clarity in the mission of an organization may stimulate an organization's members to engage in organizational tasks which positively relate with the level of mission motivation and result in higher organizational performance. Clear mission statements also help organizations' members to understand why their organizations exist, what they do, for whom they do it, and what the benefits are.

Achieving the mission of an organization should be supported by stating a clear vision which depicts how their future organizations will look if they achieve their mission. In other words, "vision refers to some idealized goal that the leader wants the organization to achieve in the future" [73]. The vision will guide and determine the success of future organizational achievement and its employees by motivating stakeholders to accomplish their goals. This motivation arises as the consequence of a positive atmosphere created by the vision such as an increase in trust, and a good relationship between leaders and subordinates. Organizational vision positively affects the attribution of followers, trust in organizational leaders, and positive congruence between leader's and followers' beliefs and attitudes [74].

Mission and vision are transferred in the form of goal statements that enable organizations to operate them. The presence of operative goals in an organization is crucial because such goals depict the state of affairs which the organization tries to 
realize, the source of legitimation and existence, the source of standards for accessing the success of the organization, and an instrument to measure an organization's performance [75], although the goals must be measurable and achievable to enable organizations to accomplish them. The goals are not only stated in official terms but also embedded in a major organization's operating policies and in the daily decisions of employees that are reflected in the organization and employees' behaviour [76].

In e-government, the existence of clear mission, vision, and goals during the adoption and use process is important to maintain an organization's future directions. The mission and vision can be exhibited by top leaders who inspire a mindset change through government agencies to raise understanding of the importance of the transformation of government into e-government [77]. There is strong evidence that organizational visions can solve organizational cultural inertia during e-government adoption in government organizations such as the case of local government of Sragen [78]. Similarly, in the UK, local governments have a clear vision for "modernized" local government over a five year period where council and other services will be accessible through telephone or internet for 24 hours a day by their customers [46]. A further example is Singapore, which is held to have experienced success in egovernment adoption through having a clear vision from the early implementation stage [79]. Success can also be achieved when the government organizations establish shared values through the setting of clear goals and priority agreements with communities when adopting e-government initiatives [46].

\subsection{Bureaucratic}

Bureaucratic culture refers to an organization's culture that has clear lines of responsibility and authority based on control and power [16]. Wallach argues that organizations are managed with strong explicit rules, are hierarchical, cautious, solid and procedural, and their people work in a systematic and an organized way in an environment where responsibility and authority are in clear lines. This appears to accord with organizations within a government environment and where those with a bureaucratic culture can achieve stability [80]. Since these organizations are well integrated through rules and hierarchies and are stable, their environment enhances the adoption of technology.

In bureaucratic organizational culture, explicit regulations are formalized which means rules, procedures, norms, standard of behaviour, and communication are written [81]. This provides an organization and its people with clarity in the regulations that enable them to perform their task and influence their behaviour according to organizational regulations. The behaviour of an organization and its members is practiced due to its conformity to the explicit regulations and the resulting formalization offers internal efficiencies. In addition, the explicit formal regulations can be an effective means for achieving coordination and integration inside organizations because the organizations and its members are bound to the regulations.

Furthermore, clear hierarchies are present in organizations in a bureaucratic culture that link people through vertical and horizontal line within the organization. In hierarchical organizations, people at higher levels set or ratify policies and objectives, and then communicate to lower level or subordinates who are charged with responsibility to take necessary actions [82]. In this way, the hierarchy provides legitimacy to senior people to direct subordinates to follow desired orders in performing organizational 
tasks. Coordination between people in horizontal levels is also well performed through the clear hierarchical relationship in organizations. In organizational social relationships, the hierarchical relationships are understood as an instrument to coordinate and determine the power and status among people [83]. As the result, organizations are solid and well structured because people have clear authorities, responsibilities, and job in the organizations.

Clear regulations and hierarchies help an organization and its members gain better coordination in accomplishing their tasks. Coordination integrates and links together different people at all levels and parts of the organizations to achieve a set of collective tasks [84]. Through the coordination people can work harmoniously to complete the subdivided tasks according their role. In the context of coordination, people are interdependent and work together in achieving organizational tasks which involves identifying goals, transferring goals to activities, assigning activities to people, and managing the relationships [85].

In the context of e-government, the presence of bureaucratic culture will benefit the process of the adoption because clear and explicit regulations and hierarchies support supervision to reduce the chance of errors, disobedience, and negligent behaviour among people. The equitable treatment of government clients is also guaranteed [47]. A bureaucratic culture underpins the effort a government organization and its people to achieve their goals to adopt e-government through a structure of conformity to the regulations. The solidity of government organizations, based on clear regulations and hierarchies, create a sense of responsibility to succeed in the adopting of e-government.

\section{External and Internal Influences on Culture and Government Organization}

The culture dimensions of an organization are related to both external adaptation and internal integration [14]. In studying the four cultural dimensions and identifying their sub-dimensions, we found that adaptability and mission appear to relate to the dynamics of external adaptation [17]. These external orientation cultural dimensions encourage organizations to develop their capacity to change in response to external conditions and expectations. External demands, such as global pressure on the prevention of corruption and public management reform [86], requires government organizations to change and adapt by implementing new technology. Another example, in the UK citizens' demands to interact with government agencies through electronic devices has led to local government implementing e-government initiatives [31].

On the other hand, the involvement and bureaucratic culture dimensions are influenced by internal integration. High levels of involvement by internal stakeholders in an organization will result in positive integration between the people and the organization's interest [17]. In addition, a bureaucratic culture creates a solid, well ordered, regulated, structured, and cautious organization [16]. This means government organizations are well governed and achieve better internal integration through implementing clear rules, regulations, hierarchies and structures.

A government organization's capacity to practice change and flexibility are determined by its culture of adaptability and involvement [17]. Meanwhile, the stability 
and direction of government organizations are determined by their mission and bureaucratic cultural dimensions because government organizations are more solid and governed by clear rules, regulations, hierarchies, structures and clear organizational directions which are guided by clear mission statements $[16,17]$.

\section{Theoretical Framework}

The framework developed from the literature is depicted in Figure 1. The framework shows the role of the four cultural traits and identified sub-cultural issues in egovernment adoption at local government levels. Cultural traits of adaptability and mission have external orientation because they are driven by outside factors such as citizens, while cultural traits of involvement and bureaucratic relate to internal integration because the need of government organizations to maintain their stability and direction. All cultural dimensions influence the adoption and use of e-government local government organizations, which is the focus of this study. Our framework depicts the adoption of e-governments as derived from either mandatory or voluntary policy as found in the cases described in Section 3 and followed by supportive policies from both entities. This suggests that when e-government initiatives are adopted at local levels across a country, both central and local governments are involved in a dynamic and cohesive coordination to succeed the initiatives.

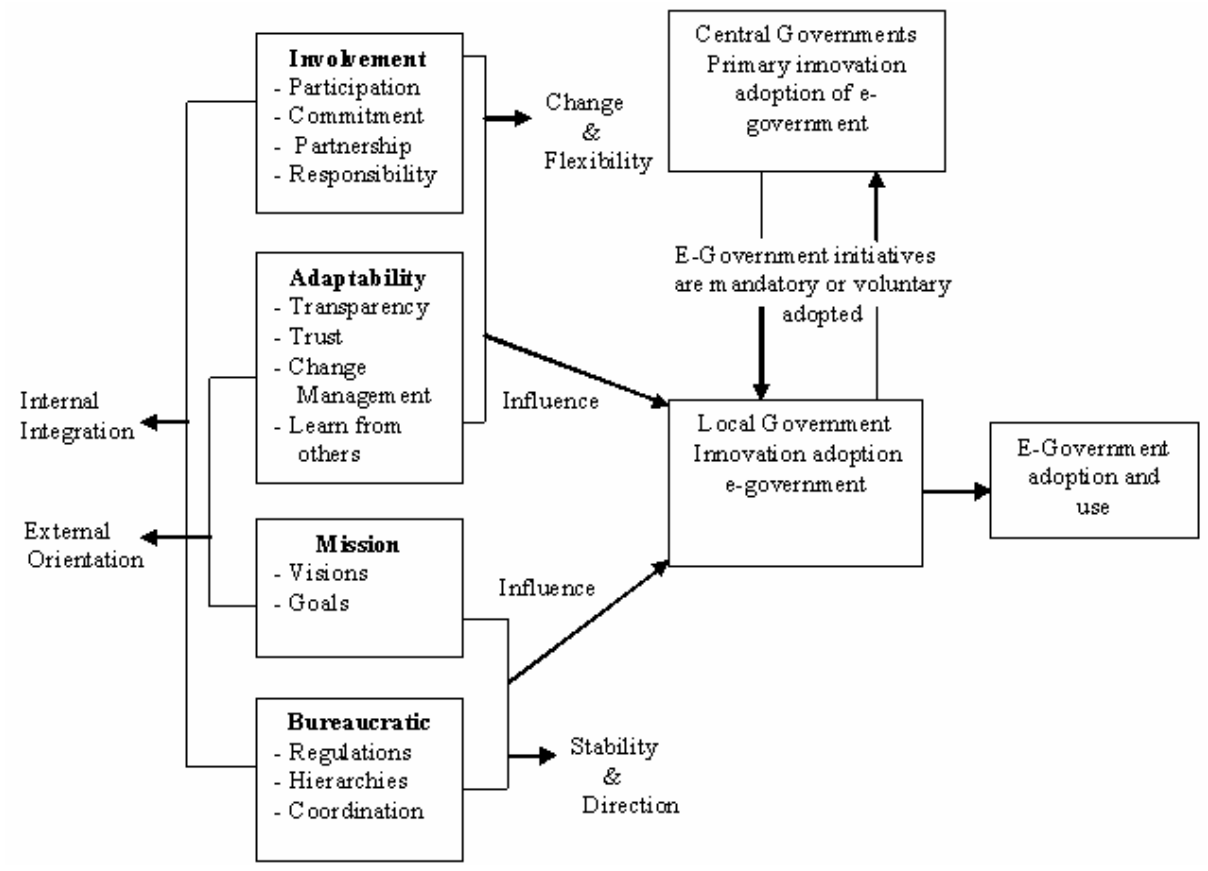

Fig. 1. The framework for exploring the role of culture in e-government adoption 


\section{Conclusions and Future Research}

The framework in Figure 1 is derived from an extensive literature review into organizational culture, public administration, information systems and technology, and egovernment literature. We have combined and modified cultural dimensions from Denison and Mishra [17], and Wallach [16] that are potentially relevant to government organizations. Further sub-cultural dimensions that support the organizational cultural dimensions have been drawn from the literature on public administration and management, IS and IT, and e-government to further inform the framework that will support exploration into local e-government adoption and use. The literature also supports the notion that adoption of e-government at local level can be mandated or voluntary both of which may be followed by supportive policies from central government through the provision of financial, political, and technical infrastructure.

Our framework represents a starting point for critical thinking in analysing cultural influences in local governments' adoption and use of electronic government. The framework is developed based on organizational culture theories that have evolved from the study of commercial organizations and may therefore have limitations in its applicability to an e-government environment. We intend to empirically test the framework to explore its validity for governmental environments and to examine for further cultural influences and interdependencies that have not yet been identified. A case study design is considered to be the appropriate method for conducting "how and why" enquiries into real world phenomena [87]. This methodology will allow for further, in-depth examination of the culture dimensions that influence and impact on local e-government adoption and use.

\section{References}

1. Dewett, T., Jones, G.R.: The Role of Information Technology in the Organization: A review, Model, and Assessment. Journal of Management 27, 313-346 (2001)

2. Iacovou, C.L., Benbasat, I., Dexter, A.S.: Electronic Data Interchange and Small Organizations: Adoption and Impact of Technology. MIS Quarterly 19(4), 465-485 (1995)

3. Cabrera, Á., Cabrera, E.F., Barajas, S.: The Key Role of Organizational Culture in a MultiSystem View of Technology-Driven Change. International Journal of Information Management 21(3), 245-261 (2001)

4. Claver, E., et al.: The Performance of Information Systems Through Organizational Culture. Information Technology \& People 14(3), 247-260 (2001)

5. Bagchi, K., Hart, P., Peterson, M.F.: National Culture and Information Technology Product Adoption. Journal of Global Information Technology Management 7(4), 29-46 (2004)

6. Romm, T., et al.: Identifying organizational culture clash in MIS implementation: When is it worth the effort? Information \& Management 21(2), 99-109 (1991)

7. Ho, A.T.K., Ni, A.Y.: Explaining the Adoption of E-Government Features: A Case Study of IOWA County Treasurer's Offices. The American Review of Public Administration 34(2), 164-180 (2004)

8. Dasgupta, S., Gupta, B.: Role of Organizational Culture in Internet Technology Adoption: An Empirical Study. In: Proceedings of Americas Conference on Information Systems (AMCIS) 2008, pp. 1304-1311 (2005) 
9. Heeks, R.: Most E-Government for Development Projects Fail: How can Risks be Reduced? (2003), http: / / unpan1 .un.org/intradoc/groups / public / documents /CAFRAD/UNPAN011226.pdf (cited 200915 November)

10. Heeks, R.: E-Government in Africa Promise and Practice. Information Polity 7(3), 97-114 (2002)

11. Hofstede, G.: Identifying Organizational Subcultures: An Empirical Approach. Journal of Management Studies 35(1), 1-12 (1998)

12. Sathe, V.: Implications of corporate culture: A manager's guide to action. Organizational Dynamics 12(2), 5-23 (1983)

13. Denison, D.R.: Corporate Culture and Organizational Effectiveness. John Wiley \& Sons, Toronto (1990)

14. Schein, E.H.: Organizational culture. American Psychologist 45(2), 109-119 (1990)

15. Denison, D.R.: What is Different Between Organizational Culture and Organizational Climate? A Native's Point of View on A Decade of Paradigm Wars. Academy of Management Review 21(3), 619-654 (1996)

16. Wallach, E.J.: Individuals and Organizations: The Cultural Match. Training \& Development Journal 37(2), 28 (1983)

17. Denison, D.R., Mishra, A.K.: Toward a Theory of Organizational Culture and Effectiveness. Organizational Science 6(2), 204-223 (1995)

18. Martin, E.C., Terblance, F.: Building Organizational Culture That Stimulates Creativity and Innovation. European Journal of Innovation Management 6(1), 64-74 (2003)

19. Weber, Y., Pliskin, N.: The effect of Information System Integration and Organizational Culture on a Firm's Effectiveness. Information \& Management 30(81-90), 81 (1996)

20. Cooper, R.B.: The Inertial Impact of Culture on IT Implementation. Information \& Management 27(1), 17-31 (1994)

21. Sriramesh, K., Grunig, J.E., Dozier, D.M.: Observation and Measurement of Two Dimensions of Organizational Culture and Their Relationship to Public Relations. Journal of Public Relation Research 8(4), 229-261 (1996)

22. Fichman, R.G., Kemerer, C.F.: The Assimilation of Software Process Innovations. An Organizational Learning Perspective Management Science 43(10), 1345-1363 (1997)

23. Moore, G.C., Benbasat, I.: Development of Instrument to Measure the Perceptions of Adopting an Information Technology Innovation. Information Systems Research 2(3), 192-222 (1991)

24. Rogers, E.M.: Diffusion of Innovations, 5th edn. Free Press, New York (2003)

25. Agarwal, R., Prasad, J.: The Role of Innovation Characteristics and Perceived Voluntariness in the Acceptance of Information Technologies. Decision Sciences 28(3), 557-582 (1997)

26. Venkatesh, V., David, F.R.: A Theoretical Extension of the Technology Acceptance Model: Four Logitudinal Field Studies. Management Science 46(2), 186-204 (2000)

27. Agarwal, R.: Individual Acceptance of Information Technologies. In: Zmud, R.W. (ed.) Framing the Domains of IT Management, Pinnaflex Education Resources 2000, pp. 85104 (2000)

28. Gallivan, M.J.: Organizational Adoption and assimilation of Complex Technological Innovations: Development and Application of a New Framework. The DATA BASE for Advances in Information Systems 32(3), 51-85 (2001)

29. Warkentin, M., et al.: Encouraging Citizen Adoption of E-Government by Building Trust. Electronic Markets 12(3), 157-162 (2002)

30. Beynon-Davies, P., Williams, M.D.: Evaluating Electronic Local Government in the UK. Journal of Information Technology 18(2), 137-149 (2003) 
31. Baynon-Davies, P., Martin, S.: Electronic Local government and the Modernization Agenda: Progress and Prospects for Public Service Improvement. Local Government Studies 30(2), 214-229 (2004)

32. Griffin, D., Halpin, E.: An Exploratory Evaluation of UK Local e-Government From an Accountability Perspective. The Electronic Journal of e-Government 3(1), 13-28 (2005)

33. Aubert, B.A., Hamel, G.: Adoption of Smart Cards in the Medical Sector: the Canadian Experience. Social Science \& Medicine 53(7), 879-894 (2001)

34. Heeks, R.: E-government as a Carrier of Context. Journal of Public Policy 25(1), 51-74 (2005)

35. Moon, M.J.: The Evolution of E-Government Among Municipalities: Rhetoric or Reality? Public Administration Review 62(4), 424-433 (2002)

36. Norris, D.F., Moon, M.J.: Advancing E-Government at the Grassroots: Tortoise or Hare? Public Administration Review 65(1), 64-75 (2005)

37. Lee, S.M., Tan, X., Trimi, S.: Current Practices of Leading E-Government Countries. Communication of the ACM 48(10), 99-104 (2005)

38. Eggers, W.D.: Boosting E-Government Adoption (2004), http: / / www.taxadmin.org/FTA/Meet/04am_pres /eggers.pdf (cited 201003 May)

39. Ho, S.Y., Ho, K.W.K.: Success of Electronic Government Information Portal: technological Issues or Manageria Issues? Journal of E-Government 3(2), 53-74 (2006)

40. Sahu, G.P., Gupta, M.P.: Users' Acceptance of E-Government: a Study of Indian Central Excise. International Journal of Electronic Government Research 2007 3(3), 1-21 (2007)

41. Schuppan, T.: E-Government in Developing Countries: Experiences from sub-Saharan Africa. Government Information Quarterly 26(1), 118-127 (2009)

42. Janssen, M., Chun, S.A., Gil-Garcia, J.R.: Building the next generation of digital government infrastructures. Government Information Quarterly 26(2), 233-237 (2009)

43. Rose, M.: Democratizing information and communication by implementing e-government in Indonesian regional government. The International Information \& Library Review 36(3), 219-226 (2004)

44. Leidner, D.E., Kayworth, T.: Review: A Review of Culture in Information System Research: Toward a Theory of Information Technology Culture Conflict. MIS Quarterly 30(2), 357-399 (2006)

45. Dada, D.: The Failure of E-Government in developing Countries: A Literature review. The Electronic Journal of Information Systems in Developing Countries 26(7), 1-10 (2006)

46. Ferguson, M.: Local E-Government in the United Kingdom. In: Local Electronic Government by Helmut Druke. Routledge, Hoboken (2004)

47. Ho, A.T.K.: Reinventing Local Governments and The E-Government Initiative. Public Administration Review 62(4), 434-444 (2002)

48. Pan, G., et al.: Escalation and De-Escalation of Commitment: A Commitment Transformation Analysis of an E-Government Project. Information Systems 2006 6, 3-21 (2006)

49. Getao, K.W., Wausi, A.N.: Organizational cultural dynamics and information and communication technology adaptation in a developing country: The case of the Kenyan joint university admission system. Information Technology for Development 2009 5(3), 224-232 (2009)

50. Schaper, K.L., Pervan, G.P.: Developing a Model Technology Acceptance Within the Australian Healthcare Sector. In: The Tenth Pacific Asia Conference on Information Systems (PACIS 2006), pp. 835-847 (2007)

51. Barki, H., Hartwick, J.: Rethinking the Concept of User Involvement. MIS Quarterly 13(1), 53-63 (1989) 
52. Hartwick, J., Barki, H.: Explaining the Role of User Participation in Information System Use Management Science 40(4), 440-465 (1994)

53. Luk, S.C.Y.: The impact of leadership and stakeholders on the success/failure of egovernment service: Using the case study of e-stamping service in Hong Kong. Government Information Quarterly 26(4), 594-604 (2009)

54. Rowlinson, S.: Matrix Organization Structure, Culture and Commitment: A Hong Kong Public Sector Case Study of Change. Construction Management and Economics 19(7), 669-673 (2001)

55. Boxx, W.R., Randi, Y.O., Dunn, M.G.: Organizational Values and Value Congruency and Their Impact on Satisfaction, Commitment, and Cohesion: an Empirical Examination Within the Public Sector. Public Personnel Management 20(2), 195 (1991)

56. Sethi, N., Sethi, V.: Public-Private-People Partnership in E-Government: A case Study of Singapure Tracks. In: Delivering E-Government by Sahu, G.P. (2006),

http : / / www . iceg . net / iceg2006 deg . pdf\#page =188 (cited 200924 November)

57. Jae-Nam, L., Young-Gul, K.: Effect of Partnership Quality on IS Outsourcing Success: Conceptual Framework and Empirical Validation. Journal of Management Information Systems 15(4), 29-61 (1999)

58. Prenclergast, C.J.: A Theory of Responsibility in Organizations. Journal of Labor Economics 13(3), 387-400 (1995)

59. Berkowitz, L., Daniels, L.R.: Responsibility and Dependency. Journal of Abnormal and Social Psychology 66(5), 429-436 (1963)

60. Scott, M., Golden, W., Hughes, M.: Implementation Strategies for E-Government: A Stakeholder Analysis Approach. In: Proceedings of 2004 European Conference on Information Systems (ECIS), pp. 1-14 (2004)

61. Tan, C.W., Pan, S.L., Lim, E.T.K.: Managing Stakeholder Interest in E-Government Implementation: Lesson Learned from a Singapore E-Government Project. Journal of Global Information Management 13(1), 31-53 (2005)

62. Jarvenpaa, S.L., Ives, B.: Executive Involvement and Participation in the Management of Information Technology. MIS Quarterly 15(2), 205-227 (1991)

63. Denison, D.R., Haaland, S., Goelzer, P.: Corporate Culture and Organizational Effectiveness: Is There a Similar Pattern Around the World? Advance in Global Leadership 3, 205 227 (2003)

64. Christensen, L.T.: Corporate Communication: The Challenge of Transparency. Corporate Communications: An International Journal 7(3), 162-168 (2002)

65. Mitchell, R.B.: Sources of Transparency: Information System in International Regimes. International Studies Quarterly 42, 109-130 (1998)

66. William, C.C.: Trust Diffusion: The Effect of Interpersonal Trust on Structure. Function and Organizational Transparency Business \& Society 44(3), 357-368 (2005)

67. Mayer, R.C., Davis, J.H., Schoorman, F.D.: An Integrative Model of Organizational Trust Academy of Management Review 20(3), 709-734 (1995)

68. Markus, M.L., Robey, D.: Information Technology and Organizational Change: Causal Structural in Theory and research. Management Science 34(5), 583-598 (1988)

69. Greenwood, R., Hinings, C.R.: Understanding Radical Organizational Change: Bringing Together the Old and the New Institutionalism. Academy of Management Review 21(4), 1022-1054 (1996)

70. Argyris, C.: Organizational Learning and Management Information Systems. DataBase, 3 11 (Winter-Spring 1982) 
71. Leuthesser, L., Kohli, C.: Corporate identity: The role of mission statements. Business Horizons 40(3), 59-66 (1997)

72. Fairhurst, G.T., Jordan, J.M.: Why are we here? Managing the meaning of an organizational mission statement. Journal of Applied Communication Research 25(4), 243 (1997)

73. Conger, J.A., Kangungo, R.N.: Toward a Behavioral Theory of Charismatic Leadership in Organizational Settings. Academy of Management Review 12(4), 637-647 (1987)

74. Awamleh, R., Gardner, W.L.: Perception of Leader Charisma and Effectiveness: The Effect of Vision Content. Delivery, and Organizational Performance Leadership Quarterly 10(3), 345-373 (1999)

75. Etzioni, A.: Two Approaches to Organizational Analysis: A Critique and a Suggestion. Administrative Science Quarterly 5(2), 257-278 (1960)

76. Perrow, C.: The Analysis of Goals in Complex Organizations. American Sociological Review 25(6), 854-866 (1961)

77. Kei, W., Wei, K.K.: Successful E-Goverment in Singapore. Communications of The ACM 47(6), 95-99 (2004)

78. Farholt, B., Wahid, F.: E-Government Challenge and The Role of Political Leadership in Indonesia: The Case of Sragen. In: Proceedings of the 41st Hawaii International Conference on System Sciences 2008, pp. 1-10 (2008)

79. Srivastava, S.C., Teo, T.S.H.: Electronic Government As A guided Evolution in Singapore: Vision For The World in The 21st Century. In: Academy of Management Best Conference paper 2005 PNP:EI, pp. 1-6 (2005)

80. Claver, E., et al.: Public Administration From Bureaucratic Culture to Citizen-Oriented Culture. The International Journal of Public Sector Management 12(5), 455-464 (1999)

81. Inkson, J.H.K., Pugh, D.S., Hickson, D.J.: Organization Context and Structure: An Abbreviated Replication. Administrative Science Quarterly 15(3), 318-329 (1970)

82. Ouchi, W.G.: The Transmission of Control Through Organizational Hierarchy. Academy of Management Journal 21(2), 173-192 (1978)

83. Mahoney, T.A.: Organizational Hierarchy and Position Worth. Academy of Management Journal 22(4), 726-737 (1979)

84. Van De Ven, A.H., Delbecq, A.L.: Determinants of Coordination Modes Within Organizations. American Sociological Review 41(2), 322-338 (1976)

85. Malone, T.W., Crowston, K.: What is Coordination Theory and How can It Help Design Cooperative Work System. In: Proceedings of the Conference on Computer Supported Cooperative Work, Los Angeles, California, October 1990, pp. 357-370 (1990)

86. Wong, W., Welch, E.: Does E-Government Promote Accountability? A Comparative Analysis of Website Openness and Government Accountability. Governance: An International Journal of Policy, Administration, and Institutions 17(2), 23 (2004)

87. Yin, R.K.: Case Study Research - Design and Method, 3rd edn. Sage, Thousand Oaks (2003) 